\title{
Study of maternal and foetal outcome in multifetal pregnancy
}

\author{
Pranjal Sanjay Nimbalkar*, Amarjeet Bava, Yogeshwar Nandanwar
}

Department of Obstetrics and Gynaecology, Lokmanya Tilak General Hospital and Municipal Medical College, Sion, Mumbai, Maharashtra, India

Received: 30 July 2016

Accepted: 30 August 2016

\section{*Correspondence:}

Dr. Pranjal Sanjay Nimbalkar,

E-mail: pranjal.nimbalkar@gmail.com

Copyright: ( ) the author(s), publisher and licensee Medip Academy. This is an open-access article distributed under the terms of the Creative Commons Attribution Non-Commercial License, which permits unrestricted non-commercial use, distribution, and reproduction in any medium, provided the original work is properly cited.

\section{ABSTRACT}

Background: Development of two or more foetuses simultaneously in the uterus is termed as multifetal pregnancy. Such pregnancies are associated with increased risk for both mother and child, and this risk increases with the number of offspring's. The incidence of multifetal pregnancies in LTMMC hospital, Sion during study period was $1.7 \%$. The overall increase in prevalence of multifetal births is of concern because the corresponding increase in the rate of preterm birth compromises neonatal survival and increases the risk of lifelong disability.

Methods: Descriptive retrospective analysis of 187 twin pregnancies and 4 triplets was done in our hospital from year January to December 2015. Patients were studied for any adverse antenatal outcome, mode of delivery, and pregnancy outcome both maternal and perinatal.

Results: In our study $89 \%$ patients belonged to age group 21-30 years. 59\% cases were booked and attended antenatal clinic on regular basis. Most of patients with twin pregnancy were primigravida (70\%). Commonest obstetric complication was preterm labor (18\%). Intrauterine death in 3\% and intrauterine growth retardation in $24 \%$ were detected during the antenatal follow ups. Out of $187+1,42 \%$ delivered by vaginal route whereas $58 \%$ patients required Caesarean section. Malpresentation being the commonest indication for caesarean in $50 \%$ cases.

Conclusions: Risk of pregnancy related complication in twins is definitely more than singleton pregnancy. Early diagnosis, careful monitoring of foetal wellbeing throughout pregnancy, administration of corticosteroids and tocolytics, regular antenatal checkups, adequate rest and institutional delivery having level 3 neonatal back up facilities can improve maternal and perinatal outcome in these patients. Motivating mothers for feeding and taking proper nutrition will help in preventing health problems in babies.

Keywords: Twin pregnancy, Triplets, Maternal outcome, Perinatal outcome, Pre-term labour

\section{INTRODUCTION}

Development of two or more foetuses simultaneously in the uterus is termed as multifetal pregnancy. ${ }^{1}$ Such pregnancies are associated with increased risk for both mother and child, and this risk increases with the number of offspring's. The incidence of monozygotic twins is uniform throughout the world as 3.5 per 1000 live births; whereas, the incidence of dizygotic twins varies between 4 and 50 per 1000 live births as it is affected by multiple factors such as use of assisted reproductive technology (ART), ethnic differences and maternal age. ${ }^{2}$ The incidence of multifetal pregnancies during study period at our institute was $1.7 \%$. The overall increase in prevalence of multifetal births is of concern because the corresponding increase in the rate of preterm birth compromises neonatal survival and increases the risk of lifelong disability. Neonates of such patients are at high risk for developing RDS (respiratory distress syndrome). Other major morbidities are intraventricular haemorrhage, periventricular leukomalacia, retinopathy of prematurity, necrotizing enterocolitis, patent ductus arteriosus and nosocomial infections. Twining is multi factorial phenomenon principally attributable to genetic 
environmental factors such as advanced maternal age. ${ }^{3,4}$ Twins are associated with variety of maternal and foetal complication. Placental physiology has a significant impact on fetal and neonatal outcome. Mono chorionic twin gestation are at higher risk of preterm labour, discordant foetal growth abnormal vascular communications, foetal malformations, cord complication and still births. ${ }^{5}$ Although twins occur in approximate 1 in 80 pregnancy, they account for $12.2 \%$ of preterm births and $15.4 \%$ neonatal death. Compared to singleton pregnancy the perinatal mortality, morbidity and long term neurological developmental disability are increased 5-10 fold in twin pregnancy. ${ }^{6}$ Triplets can be monozygotic, dizygotic or Trizygotic. Naturally occurring triplet births occurs in approximately 1 per 7000 to 10,000 births. Chorionicity can be evaluated by First and second trimester ultrasound studies.

\section{METHODS}

Descriptive retrospective analysis of 187 twin pregnancies and 4 triplets was done in Lokmanya Tilak Municipal General Hospital from year January to December 2015. Patients were studied for any adverse antenatal outcome, mode of delivery, and pregnancy outcome both maternal and perinatal outcome. All women with multifetal admitted in antenatal period or during labour were enrolled in this study. All premature babies were kept in NICU under supervision and were given nasogastric feed or parenteral fluid till they were capable of taking breast milk. Women with twin or triplet who have completed 28 weeks of gestation without any associated complications were included in the study. Individual patient's parameters like age, parity, gestational age, mode of delivery, antepartum, intrapartum and postpartum complications were studied and tabulated. Results of routine and specialised investigations including ultrasonography and Doppler studies were recorded. Data thus obtained was analysed and results studied.

\section{RESULTS}

Majority of patients studied were in age group of 21-30 yrs. $70 \%$ were primigravidas whereas $30 \%$ were multigravidas.

Most of the patients (59\%) were registered in our hospital and $41 \%$ were unregistered with us and referred patients from peripheral and private hospitals.

History of probable etiological factors revealed that patients who conceived spontaneously were 59\% and those who underwent infertility treatment were $34 \%$. Family history of twinning was obtained in $7 \%$ of cases. Thus over half of the patients had no etiological factors. Of the 4 triplets; 3 patients had taken Infertility treatment and 1 patient had family history of twinning.
Table 1: Distribution of patients according to age.

\begin{tabular}{|lll|}
\hline Patients age & No. of patients & Percentage \\
\hline$<20$ & - & - \\
\hline $21-25$ & 84 & $45 \%$ \\
\hline $26-30$ & 82 & $44 \%$ \\
\hline $31-35$ & $19+2$ & $10 \%$ \\
\hline$>35$ & $2+2$ & $1 \%$ \\
\hline
\end{tabular}

Table 2: Distribution of patients according to parity.

\begin{tabular}{|lll|}
\hline Parity & No. Of patients & Percentage \\
\hline Primigravida & $131+3$ & $70 \%$ \\
\hline Second gravida & $54+1$ & $28.8 \%$ \\
\hline Third gravida & 2 & $1 \%$ \\
\hline
\end{tabular}

Table 3: Distribution of patients by probable ethology all factors.

\begin{tabular}{|lll|}
\hline Parameters & No. of patients & Percentage \\
\hline $\begin{array}{l}\text { Spontaneous } \\
\text { conception }\end{array}$ & 110 & 59 \\
\hline $\begin{array}{l}\text { Infert treatment } \\
\text { taken }\end{array}$ & $64+3$ & 34 \\
\hline $\begin{array}{l}\text { Family history of } \\
\text { twinning }\end{array}$ & $13+1$ & 7 \\
\hline
\end{tabular}

Table 4: Distribution of the patients by their mode of delivery.

\begin{tabular}{|lll|}
\hline Mode of delivery & No. of patients & Percentage \\
\hline Vaginal delivery total & 79 & 42 \\
\hline Spontaneous & 23 & \\
\hline Assisted breech & 17 & \\
\hline Instrumentation & 6 & 58 \\
\hline $\begin{array}{l}\text { Caesarian delivery } \\
\text { total }\end{array}$ & $108+1$ & \\
\hline Abortions & $0+3$ & \\
\hline
\end{tabular}

Table 5: Indications for caesarian delivery.

\begin{tabular}{|lll|}
\hline Indications & No. of patients & Percentage \\
\hline Malpresentations & & total 50\% \\
\hline First baby & 30 & 14 \\
\hline Second baby & 24 & 5 \\
\hline Foetal distress & 15 & 8 \\
\hline $\begin{array}{l}\text { Cephalo pelvic } \\
\text { disproportion }\end{array}$ & 6 & 17 \\
\hline Non-progress & 8 & 6 \\
\hline $\begin{array}{l}\text { Previous } \\
\text { caesarian delivery }\end{array}$ & 18 & \\
\hline $\begin{array}{l}\text { Umbilical artery } \\
\text { Doppler changes } \\
\text { (IUGR) }\end{array}$ & 7 & \\
\hline
\end{tabular}


Table 6: Neonatal outcome.

\begin{tabular}{|llll|}
\hline Outcome & $\begin{array}{l}\text { No. of } \\
\text { babies }\end{array}$ & Triplets & Percentage \\
\hline $\begin{array}{l}\text { Fresh still } \\
\text { birth }\end{array}$ & 10 & 3 \\
\hline $\begin{array}{l}\text { Neonatal } \\
\text { death }\end{array}$ & 14 & 4 \\
\hline Preterm & 70 & & 18 \\
\hline IUGR & 89 & 3 & 24 \\
\hline $\begin{array}{l}\text { Term } \\
\text { normal }\end{array}$ & 191 & & 51 \\
\hline Total & 374 & 3 & \\
\hline
\end{tabular}

Table 7: Preterm.

\begin{tabular}{|l|l|}
\hline Low birth weight & No. of babies \\
\hline $1-1.5 \mathrm{kgs}$ & 27 \\
\hline $1.5-2 \mathrm{kgs}$ & 35 \\
\hline $2-2.5 \mathrm{kgs}$ & 08 \\
\hline
\end{tabular}

Out of total vaginal deliveries 30 patients delivered preterm and out of total Caesarian section 5 patients were preterm. Out of 4 patients which were triplets 3 underwent early trimester abortions and 1 patient delivered preterm by Caesarian section. Total preterm patients were 35 and total term patients were 152 .

Main indication for Caesarean section in our study was malpresentation. Almost 50\% of the patients were posted electively for malpresentation. Other indications were foetal distress, non-progress, IUGR with Doppler changes and previous Caesarean section.

34 babies required NICU care due to prematurity. Rest preterm and IUGR babies were kept in Nursery for observation. There were 10 perinatal deaths of which 7 were intrauterine foetal deaths detected antenatally with macerated still births and 3 were fresh still births. There was no maternal mortality. There were 14 neonatal deaths.

\section{DISCUSSION}

Incidence of twins in the present study $(1.7 \%)$ was much higher than reported in other studies. It could mainly be because of the referral of twin pregnancies to this hospital from other hospitals around for (NICU) neonatal care of low birth weight and premature babies. In present study $85 \%$ of twin gestation were in age group of 26-35 years as compared to study done by Spellacy et al shows 55\% of twins in same age group. In our study family history of twinning were $7 \%$ whereas study done by Chowdhury and Sultana shows family history of twinning as $19 \%$ and $30 \%$ respectively ${ }^{7,8,9}$. Majority of the patients $(59 \%)$ who were twins conceived spontaneously. Patients who conceived with IVF treatment were $34 \%$. Our study showed that $70 \%$ of patients were primigravida remaining were $30 \%$ were multigravidas whereas in studies done by Choudhry showed $64 \%$ multigravida had twins. An even higher frequency (84\%) of twinning in multigravida were reported in study done by Spellacy et al. ${ }^{7,9}$ Women with this or any associated complications were admitted in the ward for safe confinement. Irrespective of various treatment modalities like adequate rest, good diet, tocolytics and prophylactic cerclage, many women had premature onset of labour with resultant birth of premature babies. The incidence of low birth weight and extreme low birth weight was very high. There were 10 neonatal deaths accounted in our study. The incidence of having a baby with a low birth weight (less than 2500 gms) was $82 \%$ in the present study, which was much higher than reported $(51.3 \%$ ) by Australia's Mothers and Babies, AIHW, 2011 for twin pregnancies.There was no maternal mortality in this study. Consistent with this study, Chowdhury and Sultana also did not report any maternal mortality. ${ }^{7,8}$ LSCS was the commonest mode of delivery $(58 \%)$ in our study with malpresentation being the commonest indication (50\%).

\section{CONCLUSION}

Complications associated with higher order pregnancies cannot be prevented but can be detected early and controlled adequately by proper and prompt management. Perinatal deaths can be prevented by averting preterm births by combined measures like good rest, prophylactic cervical encerclage, short term tocolysis and administration of glucocorticoids. Timely diagnosis and treatment of nutritional anaemia and pre-eclampsia helps in preventing additional complications. Institutional delivery and provision of level 3 neonatal care helps in improving perinatal outcome. Early diagnosis and investigations to determine chorionicity helps in the management of these patients.

\section{Funding: No funding sources Conflict of interest: None declared Ethical approval: Not required}

\section{REFERENCES}

1. AICOG Obstetrics and Gynecology update. 2016;3:20-1.

2. Echeverry CJ. Multiple Gestation. In: Arias F, Daftary SN, Bhide AG (Eds). Practical Guide to High Risk Pregnancy and Delivery A South Asian Perspective, 3rd edition. New Delhi: Elsevier; 2008. Pp. 293-322.

3. Bortolus R, Parazzini F, Chatenoud L, Benzi G, Bianchi MM, Marini A. The epidemiology of multiple births. Hum Reprod Update. 1999;5:179-87.

4. HokestraC, Zhao ZZ, Lambalk CB, Willemsen G, Martin NG, Boomsma DI et al. Dizygotic twinning. Hum Reprod Update. 2008;14:37-47.

5. Pope RJ, Weintraub AY, Sheiner E. Vaginal delivery of vertex-nonvertex twins: a fading skill? Arch Gynecol Obstet. 2010;282:117-20. 
6. Multiple Pregnancies: The Management of Twin and Triplet Pregnancies in the Antenatal Period. NICE Clinical Guidelines, No. 129. National Collaborating Centre for Women's and Children's Health (UK). London: RCOG Press; 2011 Sep.

7. Chowdhury S. Clinical Study on twin pregnancy, FO S, Bangladesh College of Physicians and Surgeons, Dhaka, 1998.
8. Sultana H. Foetal and maternal outcome of twin pregnancy. A study of 50 cases, Bangladesh College of Physiciansand Surgeons, Dhaka, 2002.

9. Spellacy WN, Haricller A, Ferre CD. A case control study of1253 twin pregnancies from 1982-1987. Perinatal Data Base. 1990;75:198-71.

Cite this article as: Nimbalkar PS, Bava A, Nandanwar Y. Study of maternal and foetal outcome in multifetal pregnancy. Int J Reprod Contracept Obstet Gynecol 2016;5:3478-81. 